\title{
Ontology and Anti-Platonism: Reconsidering Colin Gunton's Trinitarian Theology
}

\author{
King-Ho Leung \\ St Mary's College, University of St Andrews, UK
}

\begin{abstract}
Summary: This article offers a reading of Colin Gunton's trinitarian theology in light of recent theological attempts to develop accounts of 'new trinitarian ontologies' in a strongly Christian Neo-Platonic vein. In particular, this article seeks to situate Gunton's work within the broader context of late twentieth-century European thought by comparing his 'trinitarian ontology' to the anti-Platonic ontologies of Martin Heidegger and Gilles Deleuze. By way of considering the 'antiPlatonic' aspects of Gunton's trinitarian theology, this article presents his theological project as a testcase which highlights the stakes in constructing 'new' trinitarian ontologies as well as possible objections to the affirmative attitude towards Christian Neo-Platonism in contemporary theological metaphysics.
\end{abstract}

Keywords: Colin Gunton; Platonism; Trinitarian theology; ontology; metaphysics

Zusammenfassung: Dieser Artikel bietet eine Interpretation der trinitarischen Theologie Colin Guntons vor dem Hintergrund von Versuchen der jüngsten Zeit „,neue trinitarische Ontologien“ im Sinne des christlichen Neuplatonismus zu entwickeln. Dieser Aufsatz versucht insbesondere, Guntons Werk im weiteren Kontext des europäischen Denkens am Ende des 20. Jahrhunderts zu lokalisieren, indem seine „trinitarische Ontologie“ mit den anti-Platonischen Ontologien von Martin Heidegger und Gilles Deleuze verglichen wird. Auf dem Wege einer genaueren Betrachtung der „anti-platonischen“ Aspekte von Guntons trinitarischer Theologie präsentiert dieser Aufsatz sein theologisches Projekt als Testfall sowohl zur Einschätzung dessen, was bei der Konstruktion „neuer“ trinitarischer Theologien auf dem Spiel steht, als auch zur Reflexion möglicher Einwände, die gegenüber der positiven Einstellung gegenüber dem christlichen Neuplatonismus in der gegenwärtigen theologischen Metaphysik erhoben werden können.

Schlüsselwörter: Colin Gunton; Platonismus; Trinitarische Theologie; Ontologie; Metaphysik

Recent theology has witnessed a strong revived interest in metaphysical speculation and particularly explicit attempts to develop accounts of 'new trinitarian ontology' - as expressed at the major international conference on New Trinitarian Ontologies held at the University of Cambridge in September 2019. ${ }^{1}$ However, one might argue that the attempt to construct a 'new' trinitarian

\footnotetext{
1 Video recordings of the conference available at https://www.youtube.com/playlist?list=PLR3AUOTRu-AxyNhJ67Ml6nTKSF6iy2X F (accessed 24 September 2020).
} 
ontology is not exactly new itself. Indeed, the project of developing a 'new trinitarian ontology' is one that is notably found in the works of Colin Gunton, ${ }^{2}$ one of the most influential theological voices in British theology in the 1990s who explicitly defines his work in trinitarian theology as 'a quest for ontology. ${ }^{3}$

As opposed to the 'Neo-Platonic' renaissance found in contemporary theology and much of the philosophical-theological orientations expressed at the recent Cambridge conference, Gunton's 'new trinitarian ontology' is one that very much seeks to challenge and subvert the Christian Neo-Platonic metaphysical framework assumed by many in recent philosophical theology. Indeed, while recent re-articulations of Christian Neo-Platonic metaphysics by John Milbank, David Bentley Hart, and others may be said to be 'new' trinitarian ontologies for their confident defence and re-assertion of traditional theological insights in critical response to developments in contemporary secular philosophy, Gunton's trinitarian ontology is one that is more genuinely new inasmuch as it seeks to subvert or even overthrow the 'old' AugustinianThomist or Origenist-Dionysian metaphysical frameworks defended by the likes of Milbank and Hart.

This article offers an examination of the 'newness' of Gunton's trinitarian ontology and particularly the prevalent anti-Platonic ethos of his theology. While there has been much discussion of Gunton's interpretation of patristic and scholastic theology, this article seeks to situate Gunton's intellectual project within the broader context of European thought in the second half of the twentieth century. Instead of examining Gunton's trinitarian theology, this article focusses on Gunton's ontology and specifically how his fierce critique of the 'old' Augustinian-Thomist or Origenist-Dionysian Christian 'Platonic' metaphysics corresponds to the broader trend of antiPlatonism in twentieth-century European philosophy. ${ }^{4}$ As such, this article engages primarily with

\footnotetext{
2 It is worth noting that there was, perhaps surprisingly, no mention of Gunton in any of the papers over the three-day Cambridge conference.

${ }^{3}$ Colin GunTON, The Promise of Trinitarian Theology, 2nd ed. (London: T\&T Clark, 1997), xi.

4 Although this article's 'philosophical' treatment of Gunton may differ from the usual reception of Gunton's legacy in 'systematic theology', its focus on the 'philosophical' elements of Gunton's trinitarian
} 
Gunton's two most influential and acclaimed books, The One, the Three and the Many (1992) and The Promise of Trinitarian Theology (1991; second edition 1997), which are not only regarded by many as Gunton's best and most representative works, but also where Gunton presents his most sustained genealogical critique of Christian Neo-Platonism and corresponding reflections on the task of trinitarian ontology. ${ }^{5}$ By placing Gunton within the broader context of anti-Platonic thought, this article presents Gunton's theological project as a testcase which highlights the stakes in constructing 'new' trinitarian ontologies as well as possible objections to the affirmative attitude towards Christian Neo-Platonism in contemporary theology.

The first two sections offer a reading of Gunton's anti-Platonism in relation to two of the most influential critics of Platonism in recent philosophy: Martin Heidegger and Gilles Deleuze. While Gunton does not mention the ontologies of Heidegger or Deleuze in his works, his trinitarian anti-Platonism shares a number of remarkable conceptual parallels with Heidegger's and Deleuze's philosophical critiques of Platonism. After these comparisons, this article concludes by offering some evaluative reflections on the legacy as well as the critiques of Gunton's ambitious theological project in relation to the contemporary endeavours to develop 'new trinitarian ontologies'.

\section{The Overcoming of Metaphysics}

According to Heidegger, 'metaphysics' is marked by the philosophical problem of mistaking the Being of beings as $a$ being. ${ }^{6}$ For Heidegger, this is most notably exemplified in the Christian NeoPlatonic conception of God as 'Being itself: Put simply, by identifying the Being of beings as God,

ontology is in line with Gunton's own insistence that 'systematic theology faces the same kind of questions that philosophy engages'. Colin GUNTON, 'Indispensable Opponent: The Relations of Systematic Theology and the Philosophy of Religion', Neue Zeitschrift für Systematische Theologie und Religionsphilosophie 38, no. 3 (1996): 305.

${ }^{5}$ As Christoph Schwöbel points out, Gunton's trinitarian ontology in these works 'takes up the sensibilities of post-modernity and reflects them in a trinitarian framework.' Christoph SCHWÖBEL, 'The Shape of Colin Gunton's Theology: On the Way towards a Fully Trinitarian Theology', in The Theology of Colin Gunton, ed. Lincoln Harvey (London: T\&T Clark, 2010), 199.

${ }^{6}$ Cf. Martin HeIDEgGER, Sein und Zeit, 11th ed. (Tübingen: Max Niemeyer, 1967), 6. 
who is one being, one substance or indeed one ousia, Heidegger argues that the Christian tradition fundamentally produces an 'onto-theological' conception of 'Being' which treats the Being of beings as if it were one being among other beings, reifying Being into one being among many. ${ }^{7}$ However, while Heidegger holds Christian theology largely responsible for this 'onto-theological' or 'metaphysical' conception of Being - what Heidegger calls the 'forgetting' of Being, at times Heidegger traces this forgetting of Being all the way back to the beginning of Western philosophy with Plato (or sometimes even the Pre-Socratics). ${ }^{8}$

In Heidegger's reading, by designating the idea as the measure of thought Platonic metaphysics subordinates the meaning of Being to that of essence or whatness: 'The precedence of the idea brings the ti estin along with the eidos to the position of authoritative Being. Being is primarily whatness... whatness as exclusive Being (idea as ontos on) gives more room to being itself." According to Heidegger, the precedence of whatness or essence over Being brings about a precedence of beings or entities over Being itself, which in turn allows Being itself to be mistaken as $a$ being among beings:

The precedence of whatness brings the precedence of beings themselves in what they are. The precedence of beings establishes Being as koinon [common] in terms of the ben [the one]. The eminent character of metaphysics is decided. The one as unifying unity becomes authoritative for subsequent determination of Being. ${ }^{10}$

Rather than re-visiting the controversies over Heidegger's critical interpretation of the history of philosophy and theology, ${ }^{11}$ let us focus instead on the emphasis on the notion of oneness or unity in Heidegger's critical rendition of 'metaphysics': 'The essential constitution of metaphysics is based on the unity of beings as such in the universal and that which is highest. ${ }^{12}$ In one sense, the

\footnotetext{
${ }^{7}$ Martin HeidegGer, The End of Philosophy, trans. Joan Stambaugh (New York: Harper \& Row, 1973), $15-16$.

${ }^{8}$ Cf. Martin Heidegger, Parmenides (Frankfurt am Main: Klostermann, 1982); idem, Der Anfang der abendländischen Philosophie (Frankfurt am Main: Klostermann, 2012).

${ }^{9}$ HeIDEgGER, The End of Philosophy, 55.

10 Ibid., 55, cf. 8.

11 On this issue, see John R. BETZ, 'After Heidegger and Marion: The Task of Christian Metaphysics Today', Modern Theology 34, no. 4 (2018), 565-597.

12 Martin HeIDEGGER, Identity and Difference, trans. Joan Stambaugh (New York: Harper \& Row, 1969), 61.
} 
problem Heidegger finds in the 'metaphysical' confusion of Being as $a$ being - indeed as one entity - lies in the Platonic (or even Parmenidean) elevation of the hen or oneness as the primary conceptual unifying unity of that which is thinkable. ${ }^{13}$

As alluded to above, the critique of this 'Platonic' celebration of the One is key to Gunton's understanding of the doctrine of the Trinity as a counter-Platonic resource to rethink the recurring philosophical issue of the One and the many. ${ }^{14}$ In a not dissimilar way to the Heideggerian account of the 'onto-theological' or Platonic 'forgetting' of Being, Gunton argues that much of the contemporary problems of modernity are rooted in a Platonic forgetting of the Trinity. ${ }^{15}$ According to Gunton, modern thought is characterised by 'a strong Platonist drive to turn particularities into abstractions, variety into homogeneity'. ${ }^{16}$ For Gunton, this prioritisation of the universal over the particular of the modern mindset has its genealogical roots in the Platonic metaphysical primacy of the One over the many. ${ }^{17}$ Gunton finds Christian theological tradition to be guilty of furthering this Platonic 'suppression of the many'. ${ }^{18}$ Gunton notes:

Christian theology, although it had every opportunity to develop a theology of creation in which the rights of the particular were given due place, made the major mistake of entering into the wrong kind of compromise with Platonism. ${ }^{19}$

In Gunton's story of the history of metaphysics, it is Augustine who is above all 'the fountainhead of our troubles', ${ }^{20}$ the theologian responsible for the 'Platonisation' of Western Christianity - or perhaps even Western modernity more broadly. ${ }^{21}$

${ }^{13}$ Cf. Alain BADIOU, Court traité d'ontologie transitoire (Paris: Seuil, 1998), 25-26.

${ }^{14}$ The language of 'the One' is of course more primarily developed by Plotinus's 'Neo-Platonism' instead of Plato. But in what follows this article will follow Gunton's rendition of this pattern of thought as 'Platonism'.

${ }^{15}$ Colin Gunton, The One, the Three and the Many: God, Creation and the Culture of Modernity (Cambridge: Cambridge University Press, 1993), 36. Cf. Lewis AYRES, '(Mis)Adventures in Trinitarian Ontology', in The Trinity and an Entangled World, ed. John Polkinghorne (Grand Rapids, MI: Eerdmans, 2010), 134-135.

16 GUNTON, The One, 44.

17 Ibid., 50-51, see also 41-46.

18 Ibid., 25.

${ }^{19}$ Ibid., 51.

${ }^{20}$ Colin GunTON, The Barth Lectures, ed. P.H. Brazier (London: T\&T Clark, 2007), xxiii.

${ }^{21}$ Although Origen also receives a few passing mentions in The One, the Three and the Many (see 2, 56 n.21, 81, 137, 158), it is Augustine who is undoubtedly the archvillain in Gunton's genealogical critique of modernity. See Brad GREEN, 'Protomodern Augustine? Colin Gunton and the Failure of Augustine', International Journal of Systematic Theology 9, no. 3 (2007): 328-341, especially 330; idem, 'Colin Gunton and 
In Gunton's view, there is 'a spiritualising tendency in Augustine's thought' which leads him to 'shying away from the involvement of God with the material order'. ${ }^{22}$ For Gunton, Augustine's 'anti-incarnational Platonism' is most manifest in his metaphysical rendition of the eternal Word, ${ }^{23}$ as Gunton remarks on Augustine's conception of the Word in De Trinitate XV:

The eternal Word is the word as abstract, rather than the concrete person of the Son in relation to the Father and Spirit... there is a movement away from any concrete, 'material' conceptions of the topic... [Here we see] how the platonising drive affects Augustine's discussion of the Word, who is intellectualized as part of the contents of the divine mind. ${ }^{24}$

According to Gunton, the second person of the Trinity is for Augustine not so much an incarnated concrete particular person as an intellectualised abstract universal idea that is simply 'part of the contents of the divine mind'. In Gunton's view, there is in Augustine an altogether 'replacing of Christology by Platonic universals' which 'generates a very different conception of the relation of universal and particular' from that of pre-Augustinian Christian theology such as Irenaeus' and the Cappadocian Fathers, ${ }^{25}$

As opposed to Augustine's (alleged) replacement of Christ's mediating role with Platonic universals or ideas, Gunton argues that Irenaeus provides a better trinitarian account of the ontological relation between God and creation:

Irenaeus frequently says that God creates by means of his two hands, the Son and the Spirit. This enables him to give a clear account of how God relates to that which is not God: of how the creator interacts with his creation... God creates by means of his own Son and Spirit... There do not, on this account, need to be intermediate beings between God and the world, because the Son and the Spirit mediate between the divine and the created. It is at this place that there emerges into history the classic Christian ontology. ${ }^{26}$

the Theological Origin of Modernity', in The Theology of Colin Gunton, ed. Lincoln Harvey (London: T\&T Clark, 2010), 165-181.

${ }^{22}$ Colin GunTON, The Promise of Trinitarian Theology, 2nd ed. (Edinburgh: T \& T Clark 1997), 35.

23 Ibid., 34.

${ }^{24}$ Ibid., 44, 46.

${ }^{25}$ GunTON, The One, 55-56; cf. idem, The Triune Creator: A Historical and Systematic Study (Grand Rapids, MI: Eerdmans, 1998), 73-102, especially 98.

${ }^{26}$ GunTON, The Triune Creator, 54. 
For Gunton, Irenaeus' rendition of the Son and the Spirit as the 'two hands' of God the Father provides us with 'the classic Christian ontology' because it does not posit any intermediate structures (e.g., Platonic ideas) between God and creation. ${ }^{27}$

In Gunton's account, by prioritising de deo uno over de deo trino, Augustine's 'Platonisation' of trinitarian theology facilities a problematic and dangerous metaphysical elevation of the One over the many or homogeneity over plurality which underlies the modern and postmodern understanding of societal structure and inter-personal relationships. ${ }^{28}$ What Augustine does in his trinitarian theology is to posit 'an unknown substance' that 'underlies the threeness of the persons', as a result of which the originally distinguishable identities of the three divine persons 'tend to disappear into the all-embracing oneness of God'. ${ }^{29}$ As such, Gunton argues that Augustine 'tak[es] a clear step back from the teaching of the Cappadocian Fathers' who developed 'a new ontology' that marked a clear break from classical Greek metaphysics. ${ }^{30}$

Following John Zizioulas' reading of the Cappadocian Fathers, Gunton argues that 'God's being is a being in relation, without remainder relational. ${ }^{31}$ Commenting on the Cappadocian notion of ousia, Gunton argues the 'Being' of God is not one substance, but communion:

The being of God is not now understood in the way characteristic of Greek metaphysics but in terms of communion. God is 'a sort of continuous and indivisible community' says the letter usually attributed to Basil of Caesarea. ${ }^{32}$

For Gunton, this relational conception of Being-as-communion is important not only for theology, but also for ontology in general because for him God's relational Being-as-communion is none other

\footnotetext{
27 According to Gunton, Irenaeus' 'two hand' model also upholds the continuity between God's act of creation and redemption, whereas such this link is sundered by Augustine's 'Platonisation'. See GuNTON, The One, 120, 159 n.5.

${ }^{28}$ GunTON, Promise, 30-55; see also idem, The One, 54-56.

29 GunTON, Promise, 42-43.

30 Ibid., 44.

31 Ibid., 143 , cf. 9.

32 Ibid., 94. Recent scholarship has suggested that the letter (Epistula 38) mentioned here ought to be attributed to Basil's brother Gregory of Nyssa instead.
} 
than 'the ground of being of the world and all in it. ${ }^{33}$ Indeed, as Gunton puts it: 'Accordingly, of both God and the world must be said that they have their being in relation. ${ }^{34}$

As such, what we find in Gunton's anti-Augustinian and indeed anti-Platonic presentation of the Cappadocian doctrine of God is not just a quasi-Heideggerian critique of the obfuscation of the meaning of 'Being' in Greek metaphysics, but moreover a non-reified or indeed nonsubstantialised account of the Being of beings: God's Being (i.e., 'the ground of being of the world and all in it') is not $a$ being or one substance, it is 'not a blank unity, but a being in communion'.35 As opposed to the 'Platonic' metaphysical account of 'the one as unifying unity' which Heidegger argues 'establishes Being as koinon in terms of the hen', 'Being' is not to be understood in terms of the hen, but rather primarily in terms of koinon or indeed koinonia. ${ }^{36}$ As Gunton states:

God is not God apart from the way in which Father, Son and Spirit in eternity give to and receive from each other what they essentially are. The three do not merely coinhere, but dynamically constitute one another's being... Father, Son and Spirit are eternally what they are by virtue of what they are from and to one another. Being and relation can be distinguished in thought, but in no way separated ontologically; they are rather part of the one ontological dynamic. ${ }^{37}$

To the extent that Gunton argues that Being and relation are ontologically inseparable in God, Richard Fermer critically observes that what we find in Gunton's ontology is nothing less than a 'reduction of ousia to koinonia'. ${ }^{38}$

Although the language of 'reduction' is not one that is used by Gunton himself, Fermer's critical characterisation of Gunton's (and Zizioulas') account of Cappadocian theology provides us with another perspective into how Gunton's theology 'overcomes metaphysics' in a Heideggeresque fashion. ${ }^{39}$ Gunton notes:

\footnotetext{
33 Gunton, Promise, 200.

34 Gunton, The One, 230.

35 Ibid., 214.

36 HeIDEGGER, The End of Philosophy, 55.

37 GunTON, The One, 164, 214.

38 Richard FERMER, 'The Limits of Trinitarian Theology as a Methodological Paradigm', Neue Zeitschrift für Systematische Theologie und Religionsphilosophie 41, no. 2 (1999): 165-166, 184.

39 Indeed, Fermer's use of the notion 'reduction' is meant to be pejorative. See Fermer's critique of Gunton's (and Zizioulas') interpretation of the Cappadocian Fathers in ibid., 163-169.
} 
[For the Cappadocian Fathers,] for God to be is to be in communion. Hypostases and ousia are conceptually distinct, but inseparable in thought, because mutually involve one another... Similarly, thought about the Trinity cannot proceed in abstraction from the history of salvation because the being of God is thought by means of the concrete and revealed threeness of bypostasis. ${ }^{40}$

As opposed to Augustine's later 'Platonic' postulation of 'an unknown substance supporting the three persons rather than being constituted by their relatedness' as some kind of fourth element in the Godhead, ${ }^{41}$ Gunton argues that the Cappadocians present an 'anti-Platonic' doctrine of the Trinity 'that does not float off into abstraction from the concrete history of salvation'. ${ }^{42}$ With this anti-metaphysical emphasis on 'concrete' and 'revealed' phenomena, Gunton's trinitarian ontology of Being-as-communion not only echoes Heidegger's critique of Platonic metaphysics but also his use of phenomenological reduction as a method for ontology. ${ }^{43}$

According to Heidegger, the method of reduction developed in Husserl's phenomenology provides a 'method' for ontological inquiry which replaces those of traditional ontology (what Heidegger later calls 'metaphysics'). ${ }^{44}$ For Heidegger the phenomenological approach to ontology suspends or brackets out traditional metaphysical categories that renders the Being of beings in terms of beings, and begins ontological inquiry instead with one's concrete encounter with phenomena which unfolds in time and space - bringing to light the historicity of our situated experience in time. ${ }^{45}$

\footnotetext{
${ }^{40}$ GunTON, Promise, 39, emphasis added.

${ }^{41}$ Ibid., 43.

42 Ibid., 34.

43 Of course, Gunton's emphasis that theology is to begin with concrete revelation as opposed to philosophical abstraction could be regarded as a 'straightforward Barthian' approach. See Bernhard NAUSNER, 'The Failure of a Laudable Project: Gunton, the Trinity and Human Self-understanding', Scottish Journal of Theology 62, no. 4 (2009): 404. But as Balthasar points out, Barth's own approach to theology very much echoes Heidegger's phenomenological ontology. See Hans Urs von BALTHASAR, The Theology of Karl Barth, trans. Edwards Oakes (San Francisco: Ignatius Press, 1992), 302: '[Barth] tried to provide a phenomenology of "concrete" nature in the light of revelation. Even Barth could not do without philosophy.' On the complicated relationship and parallels between Barth's theology and Heidegger's philosophy, see Kenneth OAKES, Karl Barth on Theology and Philosophy (Oxford: Oxford University Press, 2013), 84-87, 177-178.

${ }^{44}$ See HeIDEGGER, Sein und Zeit, \$\$6-7; idem, Die Grundprobleme der Pbänomenologie (Frankfurt am Main: Klostermann, 1975), $\$ 5$.

${ }^{45}$ HeIDEGGER, Die Grundprobleme, 28-29.
} 
Although his 'reduction' of ousia to koinonia is not precisely a phenomenological reduction in the Heideggerian (or Husserlian) sense, Gunton shares with Heidegger not only a deeply antiPlatonic eagerness to suspend or bracket out abstract metaphysical categories in their inquiry into the meaning of Being, but moreover a phenomenological focus on concrete phenomena as revealed historically in time. ${ }^{46}$ While Heidegger goes beyond Gunton to critique not just the Latin notion of substantia but also the Greek notion of ousia in his 'destruction' of metaphysics, ${ }^{47}$ as Fermer's critique of Gunton highlights, Gunton himself also effectively suspends the notion of ousia in his reduction of the notion of Being to koinonia or relationality. ${ }^{48}$ Moreover, echoing Heidegger's relocation of the focus of ontological inquiry from abstract metaphysical speculation to Dasein's (the phenomenological inquirer's) 'relationship towards Being', ${ }^{49}$ Gunton argues that theological inquiry 'does not begin in abstract observation, but in the work of those who stand in a particular relation to God'. ${ }^{50}$ Just as Heidegger's Dasein is defined by its relation and openness to

\footnotetext{
${ }^{46}$ One may also note the similarities between Gunton's 'non-metaphysical' rendition of God's ousia as communion in his trinitarian theology and Jean-Luc Marion's phenomenological efforts to develop a postHeideggerian account of 'God without being' - a conception of 'God' not in 'onto-theological' terms of substance or even 'being' (ens) but in relational terms of love or indeed communion. See Jean-Luc MARION, Givenness and Revelation, trans. Stephen E. Lewis (Oxford: Oxford University Press, 2016), 91, 101: 'Christian theology draws both its originality and its difficulty from the fact that it thinks unity on the basis of unicity... The unicity of God is defined, then, by the unity of communion in God... [W] ithin the horizon of the object or of beings, the principle of identity reigns, which imposes the conversion of the ens into unum and makes the unicity inversely proportional to the plurality. But things are otherwise [understood theologically] in terms of the horizon of love (of charity); in this case, and only in this case, one can say: the more relation there is between the persons, the more unity there is in the communion.' However, contrary to Gunton's conception of God's Being as a loving communion, following Heidegger's critique of onto-theology Marion draws a clear distinction between Being and love. See Jean-Luc MARION, Dieu sans l'être (Paris: Fayard, 1982). ${ }^{47}$ See Heidegger, Sein und Zeit, 26, cf. 89-92.

${ }^{48}$ Cf. John ZizIOULAS, 'Human Capacity and Human Incapacity', Scottish Joumal of Theology 28, no. 5 (1975), 407-408: 'the person can not be conceived in itself as a static entity, but only as it relates to. Thus personhood implies the "openness of being", and even more than that, the ek-stasis of being, i.e. a movement towards communion which leads to a transcendence of the boundaries of the "self"... the person in its ekstatic character reveals its being in a catholic, i.e. integral and undivided, way, and thus in its being ekstatic it becomes hypostatic... Ekstasis and hypostasis represent two basic aspects of Personhood.' While Zizioulas acknowledges that this emphasis on esktasis very much echoes Heidegger's existential ontology, particularly as interpreted through Christos Yannaras (ibid., 408 n.2; ZizIOULAS, Being as Communion, 44-45; cf. Martin HEIDEGGER, 'Brief über den "Humanismus', in Wegmarken [Frankfurt am Main: Klostermann, 1976], 313364, especially 350), to my knowledge Gunton only ever discusses Heidegger in relation to Bultmann's existentialist theology. See COLIN GUNTON, Enlightenment and Alienation (Grand Rapids, MI: Eerdmans, 1985), 121; idem, Revelation and Reason (London: T\&T Clark, 2008), 168-171.

${ }^{49}$ See HeIDEgGER, Sein und Zeit, 12.

${ }^{50}$ GunTON, Promise, 6, emphasis added.
} 
Being itself and the task of ontology is to attend to this relation, ${ }^{51}$ for Gunton to be human is 'to be related to the Father through the Son and in the Spirit, and it is the character of Christian experience to realise that relationship'. ${ }^{52}$ Indeed, as argued below, this issue of relationality very much lies at the heart of Gunton's anti-Platonic new trinitarian ontology.

\section{The Overturning of Platonism}

As a result of the metaphysical or 'Platonic' elevation of universality over particularity in philosophy and theology, Gunton argues that there has been a privileging and celebration of the One over the many in both ancient and modern culture: 'The many can find their true being and be understood only as they are related to each other and to the One. ${ }^{53}$ This is most notably exemplified in the metaphysical attribution of transcendental status to the One:

[Both ancient and modern thought] have difficulty in giving due weight to particularity, both in developing a truly relational account of what it is to be, in large part because they are in thrall to a doctrine that the one, but not the many, is of transcendental status... [It is] the dogma of the transcendental status of the one came to dominate thought at the expense of the many. ${ }^{54}$

Again, Gunton holds traditional Christian Neo-Platonic metaphysics responsible for this 'transcendental' elevation of the One:

What we see in the Origenist-Augustinian tradition is an elevating of the one over the many in respect of transcendental status. Unity, but not plurality, is transcendental. The elevation of the one is most clearly visible in the thought of Aquinas, whom I shall use as my main illustration of the downgrading of the many. ${ }^{55}$

Whereas Aquinas saw 'oneness' as a transcendental property that is 'universally applicable - to

God as well as to everything else', for Gunton this metaphysical position is misguided because it is 'developed independently of considerations of the Trinity'. ${ }^{56}$

\footnotetext{
${ }^{51}$ See note 48 above.

52 GunTON, Promise, 6.

${ }^{53}$ Gunton, The One, 37.

${ }^{54}$ Ibid., 6, 150.

55 Ibid., 138.

${ }^{56}$ Ibid., 139-140.
} 
According to Gunton, a genuinely Christian ontology must begin not with some abstract metaphysical notion of the divine one substance, but with a trinitarian conception of all being. Gunton notes:

$[\mathrm{T}]$ he doctrine of the Trinity is important... although it is not transcendental, not a mark of all being, it yet generates transcendentals, ways of looking at the universal features of the world of which we are a part and in which we live. The expectation is that if the triune God is the source of all being, meaning and truth we must suppose that all being will in some way reflect the being of the one who made it and holds it in being. ${ }^{57}$

Instead of directly making the Trinity a transcendental property, Gunton posits three transcendentals that he argues can be derived from the doctrine of the Trinity: perichoresis, relationality, and particularity (which Gunton uses synonymously with 'substantiality'). ${ }^{58}$

Defining 'perichoresis' as 'the ontological interdependence and reciprocity of the three persons of the Trinity, ${ }^{59}$ Gunton argues the Greek theological notion expresses 'the unity and plurality of the being of the God whose interaction with the world is unified and yet diversity', one which 'enables theology to preserve both the one and the many in dynamic interrelations' ${ }^{60}$ As Gunton notes:

If, as I am suggesting, the concept of perichoresis is of transcendental status, it must enable us to take a third step and begin to explore whether reality is on all its levels 'perichoretic', a dynamism of relatedness... [To] consider the world as an order of things, dynamically related to each other in time and space. It is perichoretic in that everything in it contributes to the being of everything else, enabling everything to be what it distinctively is. ${ }^{61}$

\footnotetext{
${ }^{57}$ Ibid., 145.

${ }^{58}$ Ibid., 129-141. See ibid., 195 for Gunton's explanation of his synonymous usage of particularity and substantiality. To avoid confusion, this section focusses on 'particularity' instead 'substantiality' partly because Gunton uses the term more frequently, but also because the notion of substantia is traditionally included among the Aristotelian categories, which makes it by definition not a transcendental property. Cf. Joshua MCNALL, A Free Corrector: Colin Gunton and the Legacy of Augustine (Minneapolis, MN: Fortress, 2015), 9.

${ }^{59}$ GUNTON, The One, 152.

${ }^{60}$ Ibid., 163-164.

${ }^{61}$ Ibid., 165-166.
} 
According to Gunton, this 'perichoretic' understanding of created being is not just pure metaphysical speculation, but an ontological outlook that can be supported by scientific theory, as 'many scientists have spoken the language of perichoresis in their descriptions of the universe'. ${ }^{62}$

One of Gunton's favourite 'perichoretic' examples from scientific theory is Ilya Prigogine and Isabelle Stengers' Order out of Chaos, which he quotes and commends in The One, the Three and the Many:

$[\mathrm{M}]$ any scientists have spoken the language of perichoresis in their descriptions of the universe. The way this is put in one recent study uses the conceptuality with which we are here concerned of the material universe. "Physics] now recognizes that, for an interaction to be real, the "nature" of the related things must derive from these relations, while at the same time the relations must derive from the "nature" of the things.' That is a statement of created, analogous, perichoresis. Everything in the universe is what it is by virtue of its relatedness to everything else. $^{63}$

As Stengers herself admits, her scientific theoretical collaboration with Prigogine is very much influenced by the philosophy of Gilles Deleuze. ${ }^{64}$ And indeed there are many ways in which Gunton's anti-Platonic perichoretic ontology resembles Deleuze's differential ontology which is explicitly developed as an 'overturning of Platonism'. ${ }^{65}$

As if anticipating Gunton's critique of the Platonic elevation of the One over the many, Deleuze writes in his 1968 work Difference and Repetition that Platonism 'represents the subordination of difference to the powers of the One'. ${ }^{66}$ For Deleuze to overturn Platonism is to

\footnotetext{
${ }^{62}$ Ibid., 172.

${ }^{63}$ Ibid.; citing Ilya PRIGOGINE and Isabelle STENGERS, Order out of Chaos (London: Fontana, 1985), 95. See also the discussion of this work by Prigogine and Stengers in GUNTON, Promise, 147, 152-155.

${ }^{64}$ See Isabelle STENGERS, 'Beyond Conversation: The Risk of Peace', in Process and Difference, eds. Catherin Keller and Anne Daniell (Albany, NY: SUNY Press, 2002), 235-56. See also Catherine KELLER, Face of the Deep: A Theology of Becoming (London: Routledge, 2003), 286 n.25; cf. Timothy MuRPHY, 'Quantum Ontology: A Virtual Mechanics of Becoming', in Deleuze and Guattari, eds. Kevin Jon Heller and Eleanor Kaufmann (Minneapolis, MN: University of Minnesota Press, 1998), 212: 'Prigogine has named Deleuze one of the contemporary thinkers in whom he has "found inspiration" for his work on self-organizing complex systems, such as living organisms.'

${ }^{65}$ Gilles DeLEuZE, Difference and Repetition, trans. Paul Patton (New York: Columbia University Press, 1994), 59.

66 Ibid.
} 
think of identity as secondary and subordinate to difference, and to liberate difference from the primacy of sameness and identity:

The primary distinction which Plato rigorously establishes is the one between the model and the copy... Overturning Platonism, then, means denying the primacy of original over copy, of model over image. ${ }^{67}$

According to the Platonic primacy of the original over copy, entities that deviate from the universal norm - things that are 'different' - bear very little if any resemblance or relation to the self-same original ideal. For instance, according to the Platonic schema, a poorly drawn sketch of a round clock would have little if any relation to the physical clock on which the drawing is based - let alone any relation to the perfect circle of the pre-eminent 'original' Platonic idea of (capital-C) Circularity. But if difference is understood alternatively as ontologically primary to identity and sameness - that identity and sameness are measured by just relative degrees of difference, then in principle all things - no matter how much they resemble or differ from each other - are intrinsically related to each other by virtue of difference. ${ }^{68}$

Whereas in the Platonic metaphysical regime of identity and sameness, things may be said to be unrelated to things that are utterly different from them or indeed things that are not them, according to Deleuze's anti-Platonic ontology all things - even things that have nothing common or similar between them - are intrinsically interrelated to each other. ${ }^{69}$ Not unlike Gunton's use of perichoresis as a notion 'to preserve both the one and the many in dynamic interrelations', Deleuze sees difference as an ontological term which reconciles the common antithetical tendency 'to play the one against the many, or the many against the one'. ${ }^{70}$ As Deleuze notes:

Everything is a multiplicity... the many is a multiplicity; even the one is a multiplicity... Everywhere the differences between multiplicities and the

\footnotetext{
67 Ibid., 66.

68 Ibid., see especially 66-69, 264-267; cf. Gilles DELEUZE, Logique du sens (Paris: Minuit, 1969), 292-307. ${ }^{69}$ In his later work with Félix Guattari, Deleuze's account of differential interrelatedness is further developed in more dramatic (and famous) terms of 'rhizomes' and 'assemblages'. See Gilles DELEUZE and Félix GUATTARI, A Thousand Plateaus, trans. Brian Massumi (Minneapolis, MN: University of Minnesota Press, 1987), passim. On the significance of differential relationality in Deleuze's ontology, see Daniel W. SмIтH, 'The New: The Conditions of the New', in Essays on Deleuze (Edinburgh: Edinburgh University Press, 2012), 242-255.

${ }^{70}$ GunTON, The One, 163-164, 6.
} 
differences within multiplicities replace schematic and crude oppositions. Instead of the enormous opposition between the one and the many, there is only the variety of multiplicity - in other words, difference. ${ }^{71}$

Echoing Deleuze's insistence that the intricate interrelatedness of all things does not eliminate the intrinsic difference between different particular beings and thereby reducing them to sameness, Gunton argues that 'perichoresis, properly understood, is the foe, not the agent, of homogeneity'. ${ }^{72}$ Because for Gunton, understanding perichoresis as a transcendental property shows us that everything maintains their particularity by virtue of their interrelatedness to everything else: 'Everything may be what it is and not another thing, but it is also what it uniquely is by virtue of its relation to everything else. ${ }^{, 73}$ In short, there is 'a perichoresis of all things' ${ }^{74}$

As mentioned above, Gunton draws heavily on Irenaeus' account of the 'two hands' of God to develop an alternative ontology to that of Augustine's (alleged) account of mediation by Platonic universals. In a sense, Gunton's deployment of Irenaeus against 'Christian Neo-Platonism' very much anticipates elements in Catherine Keller's Deleuze-inspired theology of becoming. As Keller writes in Face of the Deep:

Irenaeus... seeks to eliminate all mediations between God and world... An earthlyminded Christian theology will not want to trade this immanence of the world to the divine, this intimacy of the infinite, for a gnostic hierarchy. Irenaeus' God does indeed, through 'his hands' Logos and Sophia, reach out and touch matter. In this sense Irenaeus deconstructs a certain neo-platonic idealism. ${ }^{75}$

\footnotetext{
${ }^{71}$ DELEUZE, Difference and Repetition, 182.

${ }^{72}$ GunTON, The One, 172.

73 Ibid., 173.

${ }^{74}$ Ibid., 177.

75 KELLER, Face of the Deep, 51. Additionally, Gunton and Keller are both interested in re-reading Irenaeus' account of the recapitulatio of all things in relation to relativity theory. See ibid., 55-56; GUNTON, The One, 162, cf. 80, 159.
} 
Moreover, not unlike Keller's Deleuzean account of the Spirit of God as 'the differentiator which relates [one creature] to another, ${ }^{76}$ the Holy Spirit is also key to Gunton's own trinitarian account of what Keller calls 'the constitutive relationality of our creatureliness'. ${ }^{77}$

According to Gunton's neo-Irenaean rendition of the Son and the Spirit as the 'two hands' by which God creates the world, 'it is the Son who is the unifier of creation, the one in whom all things hold together', whereas the Holy Spirit is 'the one who maintains the particularity, distinctiveness, uniqueness, through the Son, of each within the unity'. ${ }^{78}$ In short, the Son is the unifier of all things while the Spirit is the particulariser or 'individuator' of all things - the ontological principle which gives particularity, individuation, or indeed haecceity to all being: 'baecceitas', as Gunton says, 'is the gift of the perfecting Spirit'. ${ }^{79}$ According to Gunton, all existent material beings are affirmed in their particularity by this pneumatology:

both persons and things, for all their crucial ontological differences, alike receive the shape of their being from the particularizing Spirit... All particulars are formed by their relationship to God the creator and redeemer and to each other. Their particular being is a being in relation, each distinct and unique and yet each inseparably bound up with other, and ultimately all, particulars. ${ }^{80}$

To the extent that Gunton's pneumatology postulates that everything is related to God and indeed interrelated to everything else through their haecceities - as opposed to their essence as 'persons' or 'things', Gunton not only echoes Keller's Deleuzean account of 'differentiator as connector' but also Deleuze's (and Guatarri's) use of the Scotist notion of haecceity to displace or indeed

\footnotetext{
${ }^{76}$ Ibid., 232, where Keller notes: 'the "relation of relations" may be called by implication the spirit of God... The Deleuzian implicatio signifies "the differentiator which relates them one to another". Differentiator as connector: thus this spirit will not transcend or obliterate differences; rather differences are intensified precisely by being brought into relation. So the third capacity thus signifies the relationality itself. Spirit as the relation of relations relates the divine interdependency to the interdependencies of the world... and as such the interrelation of all creatures.'

77 Ibid., 56.

78 GUNTON, The One, 206.

79 Ibid., 207, see also 198, 201.

80 Ibid., 207, Gunton's emphasis.
} 
overthrow the traditional metaphysical hierarchical schema of essentialism in $A$ Thousand Plateaus $(1980) \cdot{ }^{81}$

While the Deleuzean notion of haecceity in $A$ Thousand Plateaus differs slightly from Duns Scotus' original conception insofar as Deleuze conceives of haecceitas in terms of processes and events, ${ }^{82}$ Deleuze's somewhat cryptic account of 'singularities or haecceities' carried out by 'energetic materiality in movement ${ }^{83}$ is also very much echoed by Gunton's account of 'the Spirit as in some sense the energy of the Godhead':

In such a way, we may understand the Holy Spirit as the divine energy releasing the energies of the world, enabling the world to realise its dynamic interrelatedness. Thus is God the Spirit conceived as the perfecting cause, the true source of the dynamic of the forward movement of the cosmos. ${ }^{84}$

As though giving a Christianised account of Deleuze's dynamic vision of the world as a 'flow of matter-energy, ${ }^{85}$ Gunton writes:

If everything created is to be understood as energy taking various shapes, energy, indeed, deriving from the God who is triune personal energy, we can understand the world variously, as containing a variety of forms of being: sometimes the things we call material because we can see and touch them, but also sometimes those equally real and concrete things like music... we have to understand the world as energy taking all kinds of different shapes as it comes from the hand of that energetic dynamism of persons in relation, the eternal triune God. ${ }^{86}$

As opposed to the 'absolute distinction between the energies and the being of God' assumed by modern Orthodox theology following Palamas, ${ }^{87}$ Gunton argues that God's divine being is energy: 'the very being of God is dynamic and energetic', ${ }^{88}$ and created being only exists as what Gunton

\footnotetext{
${ }^{81}$ See DeLeuZE and GUATTARI, $A$ Thousand Plateaus, 260-277, especially 261, where 'haecceity' is defined as 'a mode of individuation very different from that of a person, subject, thing, or substance'. As Lewis Ayres points out, Duns Scotus plays a unique role in Gunton's genealogy of western metaphysics as 'Scotus's notion of haecceitas indicates the possibility of another way of thinking despite the dominance of the monism in the west'. See Lewis AYRES, 'Augustine, the Trinity and Modernity', Augustinian Studies 26, no. 2 (1995), 128. Cf. Deleuze's high praises of Scotus in Difference and Repetition, 35-40, 66, 303, 309, especially 35: 'There has only ever been one ontology, that of Duns Scotus.'

82 See DELEUZE and GUATTARI, $A$ Thousand Plateaus, especially 507, see also see also 369, 378, 479, 512.

${ }^{83}$ Ibid., 408.

${ }^{84}$ GUNTON, Promise, 153.

${ }^{85}$ DeleuZE and GuATtARI, $A$ Thousand Plateaus, 468, see also 56, 153, 342-343, 407-410, 460.

${ }^{86}$ GUNTON, The Triune Creator, 175-176.

${ }^{87}$ See GUNTON, Promise, 145.

88 Ibid.
} 
calls the 'taking shape' - or perhaps what Deleuze would call the 'stratification' - of the divine flow of energy. ${ }^{89}$ To this extent, not only does Gunton's theological project echo much of contemporary (secular) philosophical appropriations of Scotist ontology and haecceity, ${ }^{90}$ his dynamic account of being as energy also anticipates many ontological insights and ideas in recent philosophy and critical theory. ${ }^{91}$

\section{Re-considering Gunton's Project}

Since the turn of the century, Gunton's agenda of purging Christian theology of its historic NeoPlatonic influences has somewhat gone out of fashion, following some of the new scholarship in historical theology which calls into question the East/West divergence in trinitarian theology assumed by the so-called 'de Régnon paradigm' which (arguably) underlies Gunton's (and Zizioulas') reading of patristic theology. ${ }^{92}$ These new paradigms in the study and interpretation of patristic theology not only fostered and facilitated much of the recent theological interest in in recovering and recasting the Christian Neo-Platonic insights from not just Augustine but also Gregory of Nyssa, Dionysius the Areopagite as well as Origen for contemporary theological reflection, they also contributed to what has been called an 'apophatic turn' in trinitarian theology. ${ }^{93}$

\footnotetext{
${ }^{89}$ Cf. Deleuze and GuATTARI, $A$ Thousand Plateaus, 502: 'Stratification is like the creation of the world from chaos, a continual, renewed creation. And the strata constitute the Judgment of God. Classical artists are like God, they make the world by organizing forms and substances, codes and milieus, and rhythms.' ${ }^{90}$ In addition to Deleuze, see Giorgio AGAMBEN, The Use of Bodies, trans. Adam Kotsko (Stanford: Stanford University Press, 2016); Eugene THACKER, After Life (Chicago: The University of Chicago Press, 2010); cf. Alain BADIOU, Deleuze: The Clamor of Being, trans. Louise Burchill (Minnesota: Minnesota University Press, 1999).

${ }^{91}$ See Jane BenneTt, Vibrant Matter: A Political Ecology of Things (Durham, NC: Duke University Press, 2010); Rosi BRAIDOTTI, Posthuman Knowledge (Cambridge: Polity, 2019); Elizabeth GrOSZ, The Incorporeal: Ontology, Ethics, and the Limits of Materialism (New York: Columbia University Press, 2017); cf. AGAMBEN, The Use of Bodies, 146-175.

${ }^{2}$ See Michel René BARneS, 'De Régnon Reconsidered', Augustinian Studies 26, no. 2 (1995), 51-79; Sarah COAKLEY, 'Re-thinking Gregory of Nyssa: Introduction', Modern Theology 18, no. 4 (2002), 431-443; Sarah COAKLEY, 'Re-thinking Dionysius the Areopagite: Introduction', Modern Theology 24, no. 4 (2008), 531-540; Lewis AYRES, Nicaea and Its Legacy: An Approach to Fourth-Century Trinitarian Theology (Oxford: Oxford University Press, 2004); Lewis AYRES, Augustine and the Trinity (Cambridge: Cambridge University Press, 2010).

${ }^{93}$ See Sarah COAKLEY, God, Sexuality, and the Self: An Essay 'On the Trinity' (Cambridge: Cambridge University Press, 2013); E. Jerome VAN KuiKen, "Ye Worship Ye Know Not What"? The Apophatic Turn and the Trinity', International Journal of Systematic Theology 19, no. 4 (2017): 401-420.
} 
In contrast with this 'Christian Neo-Platonic' revival, with his avowed anti-Platonism as well as his interest in re-reading theology in light of radical scientific theories, perhaps Gunton's theological programme appears more in line with the anti-Platonic 'radical theologies' of John Caputo and Catherine Keller, who draw heavily on the atheistic philosophies of Heidegger, Deleuze, and others to develop subversive critiques of many mainline traditional theological positions. However, as opposed to Caputo's engagement with Heidegger as a mystical thinker and Keller's reading of Deleuze as a source for apophatic theology, ${ }^{94}$ Gunton's trinitarian theology is marked by a bold confidence in making cataphatic theological assertions about the divine life of the Trinity - a feature of Gunton's theological project which has also received much criticism from contemporary systematic theologians who accuse Gunton of having an insufficiently apophatic or even a 'projectionist' account of the Trinity. ${ }^{95}$

Before returning to considering Gunton's theological legacy, it is worth briefly summarising the critiques put forward by 'apophatic trinitarians' such as Karen Kilby and Sarah Coakley, as much of their critiques of Gunton are also applicable to the recent endeavours to develop new trinitarian ontologies. ${ }^{96}$ According to Kilby, attempts to construct trinitarian ontological accounts of created being in light of the uncreated divine being of the Trinity is inevitable at risk of committing what Kilby calls 'projectionism': namely, the idolatrous projection of idealised features of creaturely existence onto the divine being, and then in turn projecting these projected views back onto created being (especially human social order). ${ }^{97}$ Rather than seeing the doctrine of the Trinity as 'a descriptive, first order teaching', Kilby argues that:

\footnotetext{
${ }^{94}$ See John CAPUTO, The Mystical Element in Heidegger's Thought (New York: Fordham University Press, 1986); Catherine KELLER, Cloud of the Impossible: Negative Theology and Planetary Entanglement (New York: Columbia University Press, 2015), especially chapter 5.

${ }^{95}$ See especially Karen KILBY, 'Perichoresis and Projection: Problems with Social Doctrines of the Trinity', New Blackfriars 81, no. 95 (2000), 432-445; idem, 'Is an Apophatic Trinitarianism Possible?', International Joumal of Systematic Theology 12, no. 1 (2010), 65-77.

${ }^{96}$ Indeed, like Gunton, Kilby finds much fault with the cataphatic character of Augustine's Christian NeoPlatonic doctrine of the Trinity. See Karen KILBY, 'Aquinas, the Trinity and the Limits of Understanding', International Journal of Systematic Theology 7, no. 4 (2005), 414-427.

${ }^{97}$ Kilby's main target is 'social trinitarianism', which she argues includes Gunton's work. See KILBY, 'Perichoresis and Projection', 437-438. However, Gunton sought to distance himself from social
} 
[Trinitarian doctrine] can instead be taken as grammatical, as a second order proposition, a rule, or perhaps a set of rules, for how to read the Biblical stories, how to speak about some of the characters we come across in these stories, how to think and talk about the experience of prayer, how to deploy the 'vocabulary' of Christianity in an appropriate way. ${ }^{98}$

Understood as such, the purpose of the doctrine of the Trinity is not to paint a picture of what the Trinity or what created being is like, but rather to inform one on bow to live and think trinitarianly. ${ }^{99}$ As Kilby puts it, the task of trinitarian theology is not to enable some theoretical 'contemplation of the Trinity' but rather to facilitate the practice of 'contemplation in the Trinity', ${ }^{100}$ a theological emphasis that resonates with Coakley's 'incorporative' approach to 'praying the Trinity' contemplatively which takes much inspiration from Christian Neo-Platonism. ${ }^{101}$

In light of these critiques that emerged out of the 'apophatic turn' and the rehabilitation of Christian Neo-Platonism, Gunton's strongly cataphatic and emphatically anti-Platonic account of the Trinity may perhaps seem rather 'dated' when compared to the recent trends in contemporary trinitarian theology. However, the apparent 'datedness' of Gunton's (then) 'new' trinitarian ontology can nonetheless provide some interesting insights that are deeply relevant for contemporary theological reflection, especially in light of the recent endeavours to develop 'new trinitarian ontologies' mentioned in this article's introduction. After all, Gunton himself acknowledges that his understanding of the Trinity and of created being is by no means definitive or incontestable:

trinitarianism. See GunTON, Promise, 198; cf. The One, 190. Kilby's critique of the 'projectionism' of social trinitarianism is somewhat anticipated in Schwöbel's introduction to a collection of conference papers from the Research Institute of Systematic Theology at King's College London which he co-founded with Gunton. See Christoph SCHWÖBEL, 'The Renaissance of Trinitarian Theology: Reasons, Problems and Tasks', in Trinitarian Theology Today: Essays on Divine Being and Act, ed. Christoph Schwöbel (Edinburgh: T\&T Clark, 1995), 11: 'the relationship between our views of God and our views on the order of personal and social relationships is complex. It would be theologically disastrous if one criticized the projection of certain views of the divine nature on the order of human society for its alienating effects, and then proceeded by projecting a view of desirable human relationships on the divine being.'

${ }^{98}$ KILBY, 'Perichoresis and Projection', 443, emphasis added.

${ }^{99}$ The task and notion of 'thinking trinitarianly' is central to Gunton's project of trinitarian theology. See Colin GunTON, Father, Son, and Holy Spirit: Toward a Fully Trinitarian Theology (London: T\&T Clark, 2003), especially $6-11$.

100 KILBY, 'Aquinas', 426; 'Apophatic Trinitarianism', 72.

101 See COAKLEY, God, Sexuality, and the Self, especially chapter 3. 
There is not a 'model' known as a trinitarian doctrine, a fixed set of formularies, but rather a process of intellectual development - a tradition - during the course of which a number of conceptual possibilities have been shaped... [The aim of my work is] to show the doctrine of the Trinity not as a closed dogma, to be swallowed or not as the case not as the case may be, but a continuing enterprise of continual refinement and development. ${ }^{102}$

While one may question his eagerness to overthrow traditional Augustinian-Thomist or OrigenistDionysian accounts of the Trinity, ${ }^{103}$ Gunton's self-awareness of the contingent and limited nature of his own trinitarian theology - or indeed of all trinitarian theology per se - may be regarded as an expression of a certain apophaticism with regards to the theological tradition's ability to understand or articulate the mysteries of the Trinity. If this reading of Gunton's alternative apophaticism is plausible, then perhaps it is not unfair to say that Gunton understood his own articulation of trinitarian ontology as a contingent account particular to a specific intellectual context that is itself subject or indeed 'open' to revision. ${ }^{104}$

While Gunton's anti-Augustinian trinitarian theology could be understood as reflective of the anti-metaphysical and indeed anti-Platonic philosophical milieu in which he found himself, the aforementioned contemporary interest in 'new trinitarian ontologies' is also reflective of the recent renewed interest in speculative or even theological metaphysics in academic secular philosophy. ${ }^{105}$ Although the differences between their interpretations of the theological and philosophical legacy of Christian Neo-Platonism cannot be simply explained by the dominant philosophical positions

\footnotetext{
102 GUNTON, Promise, 195, 204.

${ }^{103}$ For Gunton, the problem with the 'classical' Augustinian account of the Trinity is that it is 'obsolete because the precise form of words in which it was formulated no longer satisfies modern rational criteria or theological developments.' Ibid., 194.

104 This 'openness' is evident in Gunton's insistence on his trinitarian account of transcendental prosperities as 'open transcendentals', see GUNTON, The One, 142: 'An open transcendental is a notion, in some way basic to the human thinking process, which empowers a continuing and in principle unfinished exploration of the universal marks of being.' Cf. SCHWÖBEL, 'The Shape of Colin Gunton's Theology'.

105 See BETZ, 'After Heidegger and Marion'. In addition to the works in continental philosophy mentioned above in notes 90-91, see also the remarks on contemporary analytic philosophy in Timothy WILLIAMSON, The Philosophy of Philosophy (Oxford: Oxford University Press, 2007), 19: 'The usual stories about the history of twentieth-century philosophy fail to fit much of the liveliest, exactest, and most creative achievements of the final third of that century: the revival of metaphysical theorizing, realist in spirit, often speculative, sometimes commonsensical... this activity must be a throwback to pre-Kantian metaphysics: it ought not to be happening - but it is.'
} 
of their respective intellectual contexts, ${ }^{106}$ the apparent 'datedness' of Gunton's anti-Platonism serves as a helpful reminder of the historical specificities and limits of all theological attempts not only Gunton's but even those of St Augustine and St Irenaeus - to understand and articulate the mysteries of the Trinity in finite human categories. ${ }^{107}$ However, this does not mean that the attempt to develop a 'trinitarian ontology' is one that is always misguided or inevitably fruitless. ${ }^{108}$ The way in which Gunton's trinitarian ontology resonates with or even anticipates many contemporary philosophical concerns highlights how the sophisticated doctrinal formulations of the Trinity in the Christian theological tradition can provide many theoretical insights and conceptual resources for the ongoing explorations into the issues of ontology and metaphysics not only for Christian theology but perhaps also secular philosophy - especially in light of its renewed interests in classical and indeed theological metaphysical questions as identified and highlighted by the 'new trinitarian ontologists' in contemporary theology.

As noted above, Gunton's attempt to articulate a new trinitarian ontology has faced much criticism in recent years - to the extent that his theological project has even been called a 'failure'. ${ }^{109}$ But perhaps, as Kilby and other 'apophatic' critics of Gunton's trinitarian project remind us in their critiques of Gunton, all theological efforts to capture or represent the mysteries of the Trinity are all bound to be 'failures' to some degree. ${ }^{110}$ Yet following Kilby's contention that trinitarian doctrinal reflection is primarily concerned with how to think and live trinitarianly, even if one disagrees with some or even most of the content of Gunton's doctrinal positions, perhaps one can still appreciate Gunton's insistence that 'the Trinity is about life, life before God, with one another and in the world... that God's life is mediated to us trinitarianly. ${ }^{111}$

\footnotetext{
106 Indeed, already in The One, Gunton fiercely critiques Milbank's affirmation of Christian Neo-Platonism over a series of footnotes. See GuNTON, The One, 55n20, 139n12, 193n16, $204 \mathrm{n} 37$.

107 Cf. Colin GunTON, Act and Being: Towards a Doctrine of the Divine Attributes (London: SCM Press, 2002), 72: "Words, all words, are created realities. None of them is from the outset qualified to describe divine being, even, or rather especially, abstract words like "being".'

108 Cf. ibid., 73-74.

${ }^{109}$ See NAUSNER, 'The Failure of a Laudable Project'.

110 Cf. KILBY, 'Apophatic Trinitarianism', 67-68.

111 GUNTON, Father, 11.
} 
Like any other theologian or indeed any human thinker, Colin Gunton is not without faults in his theological vision and articulation. But, to echo Stephen Holmes, even if one disagrees with Gunton about the content of theology, the bold vision of Gunton's theological project can nonetheless provide one with many helpful ideas about the scope and usefulness of trinitarian theology. ${ }^{112}$ In other words, even if one disagrees with Gunton about what the doctrine of the Trinity teaches, there is still much inspiration one can take from engaging with how Gunton engages with trinitarian theology to speak to the Christian life or indeed illuminate issues of ontology. ${ }^{113}$ As contemporary theology finds a renewed confidence and enthusiasm to develop trinitarian accounts of being and reality, Gunton's earlier ambitious if experimental trinitarian theological project - as well as the different criticisms and objections it received - can provide some invaluable lessons for the recent advocates of 'new trinitarian ontologies' as they seek to address various questions of metaphysics. Even if these new trinitarian ontologies may hold very different theological and philosophical orientations from those of Gunton, perhaps Gunton's trinitarian project can at the very least serve as a reminder that the doctrine of the Trinity is not just 'a piece of abstract theorizing' but one which concerned with 'the relation between theology and life... the art of living before God, with our neighbour and in the created world'.114

\footnotetext{
112 Stephen R. Holmes, 'Towards the Analogia Personae et Relationis', in The Theology of Colin Gunton, ed. Lincoln Harvey (London: T\&T Clark, 2010), 45.

113 As Schwöbel points out, the 'shape' (the what) of Gunton's conception of the Trinity's dynamic being is correlated with the dynamic 'taking shape' (the how) of his theological ideas and positions. See SCHWÖBEL, 'The Shape of Colin Gunton's Theology'.

114 GUNTON, Father, 6.
} 